Brit. F. vener. Dis. (1970) 46, 313

\title{
Reactivity in the FTA-ABS test of rabbits hyperimmunized with nonpathogenic treponemes ${ }^{(1)}$
}

\author{
G. R. TRINGALI (2) AND P. M. COX \\ From the Venereal Disease Research Laboratory, Venereal Disease Branch, National Communicable Disease \\ Center, U.S. Department of Health, Education, and Welfare, Atlanta, Georgia 30333, U.S.A.
}

In the absorption step of the fluorescent treponemal antibody-absorption (FTA-ABS) test (USPHS, 1969) sorbent is used to circumvent so-called natural antiTreponema pallidum ( $\mathrm{Tp}$ ) reactivity present in a significant proportion of presumed nonsyphilitic individuals (Hunter, Norins, Falcone, and Stout, 1968). It has been postulated that the natural reactivity may be stimulated by nonpathogenic, saprophytic treponemes (Deacon and Hunter, 1962). Sorbent is a concentrated, clarified supernatant fluid from an autoclaved Reiter broth culture prepared according to methods described by Stout Kellogg, Falcone, McGrew, and Lewis (1967). The best concentration at which the sorbent is to be used in testing human sera is determined for each lot using two main criteria. The sorbent, when mixed four parts with one part serum, should remove all natural anti- $T p$ reactivity from a number of standard human nonsyphilitic sera known to have a high degree of such natural reactivity. At the same time, the sorbent should not remove the anti- $T$ p reactivity in a number of human syphilitic sera.

In this report, we present data from an animal study showing that, in an FTA-ABS type of procedure, sera from rabbits hyperimmunized with various nonpathogenic treponemes continue to react with $T p$ after treatment with sorbent at the concentration routinely used in the FTA-ABS test. The reactivity was eliminated in most of the rabbit sera by absorption with Reiter protein antigen and in all sera by absorption with intact or sonically disrupted Reiter treponemes, both of which have been used as absorbents in earlier versions of the FTA-ABS procedure (Deacon and Hunter, 1962; Hunter, Deacon, and Meyer, 1964).

\section{Material and methods \\ ANTISERA}

Rabbit antisera to the following seven cultivatable treponemes were obtained from a previous study (Meyer

Received for publication October 15, 1969

(1) Trade names are used for identification only and do not represent an endorsement by the Public Health Service or the U.S. Department of Health, Education, and Welfare.

(2) Present address: Istituto d'Igiene, Università di Palermo, 09127, Palermo, Sicilia, Italy. and Hunter, 1967) and had been stored at $-20^{\circ} \mathrm{C}$.: English Reiter, Kazan, MRB, FM, N-39, Treponema zuelzerae, and Treponema vincentii. Antisera also were produced against intact Reiter treponemes $\left(2 \times 10^{8}\right.$ organisms $/ \mathrm{ml}$.), sonically disrupted Reiter treponemes $\left(2 \times 10^{8}\right.$ organisms $\left./ \mathrm{ml}.\right)$, and $\mathrm{Tp}\left(2 \times 10^{8}\right.$ organisms $/ \mathrm{ml}$. $)$ injected intravenously according to the methods of D'Alessandro and Zaffiro (1962). Bleedings taken before inoculation from the rabbits used for immunization were nonreactive in the FTA-ABS procedure. No adjuvants were used in any of the inoculations.

The nonpathogenic treponemes used for antibody production represent five serogroups which have been shown to be serologically related to each other and to $\mathrm{Tp}$ by a common antigen detected by direct immunofluorescence (Meyer and Hunter, 1967).

\section{CULTIVATION OF ORGANISMS}

The Reiter treponemes were grown in thioglycollate medium containing 10 per cent. normal rabbit serum and were washed and suspended in physiological saline. The $T p$ used for animal inoculations were harvested in physiological saline from rabbit testicular syphilomas. The organisms were stored at $-20^{\circ} \mathrm{C}$. until use.

\section{ABSORBENTS}

Four products of Reiter treponemes were used for the absorption of antisera before testing in the indirect fluorescent antibody assay. Saline-washed, packed Reiter organisms were mixed with antisera in a ratio of three parts antiserum to one part Reiter organisms according to the techniques used in direct immunofluorescence studies (Deacon and Hunter, 1962). The mixture was incubated for $2 \mathrm{hrs}$ at $37^{\circ} \mathrm{C}$. and then centrifuged to remove the Reiter element.

The Reiter sonicate was prepared as described in the original FTA-ABS procedure (Hunter and others, 1964) by sonically disrupting a suspension of Reiter treponemes equivalent to forty times a MacFarland No. 10 density standard. The disruption was carried out in a Raytheon sonic oscillator, $250 \mathrm{~W} ., 10 \mathrm{kc}$. $/ \mathrm{sec}$., $0-5^{\circ} \mathrm{C}$. for $1 \mathrm{hr}$. The sonicated material was centrifuged to remove any intact organisms and large particles. A portion of the Reiter sonicate was autoclaved for $10 \mathrm{~min}$. at $15 \mathrm{PSI}$ and centrifuged to remove the coagulated material.

The Reiter sorbent (supplied by the Reagents, Testing, and Evaluation Subunit of the Venereal Disease Research Laboratory) had been prepared and standardized accord- 
ing to published methods (Stout and others, 1967). One lot of sorbent standardized against human sera was used throughout this study.

The Reiter protein antigen (BB.L) employed for absorption was a concentrated stock antigen (titre $1: 40$ ) used in the Reiter protein complement- fixation (RPCF) test.

\section{INDIRECT FLUORESCENT ANTIBODY (IFA) ASSAY}

An IFA assay was used to determine the antibody level present in hyperimmune rabbit sera before and after absorption with various products of Reiter treponemes. The procedure was modelled on the FTA-ABS test (USPHS, 1969) with the following modifications:

(1) Fluorescein - isothiocyanate - labelled anti - rabbit globulin was used.

(2) Each serum was tested at 1:5 dilution made with one of the following: phosphate-buffered saline (PBS); unheated or heated sonicate of Reiter treponemes; Reiter protein antigen; or sorbent. A sample of each serum also was absorbed with whole Reiter treponemes and then diluted 1:5 in PBS.

(3) Quantitation of reactivity in each serum was performed by making serial dilutions of it in PBS. For testing, each dilution was subsequently diluted 1:5 with each of the various absorbents.

(4) Both $T p$ and Reiter treponemes were used as antigens.
The highest dilution showing a $1+$ degree of fluorescence was taken to be the endpoint titre.

The $T p$ antigen was obtained in a lyophilized state from the Reagents, Testings, and Evaluation Subunit of the Venereal Disease Research Laboratory and had been check-tested for satisfactory reactivity with reactive rabbit sera. The Reiter organisms used as antigen were described above in "cultivation of organisms". The fluorescein-isothiocyanate-labelled anti-rabbit globulin (Difco) used in this study was check-tested for satisfactory performance according to the recommendations set for the FTA-ABS test (USPHS, 1969). Before the anti-rabbit conjugate could be used in the test system, it was necessary to absorb it with Reiter treponemes to remove intrinsic reactions between the undiluted conjugate and the $\mathrm{Tp}$ and Reiter antigens. The conjugate was used routinely at a 1:30 dilution.

\section{Results}

The results show that hyperimmunization of rabbits with a variety of nonpathogenic treponemes yields antisera reactive in the IFA assay using both $\mathrm{Tp}$ (Table I) and Reiter treponemes (Table II) as antigens. The antisera, which had antibody titres ranging from $1: 5$ to $1: 640$, were no longer reactive to either antigen after absorption with intact or sonically disrupted Reiter treponemes. Absorption

TABLE I Anti-Treponema pallidum reactivity of rabbit antisera to cultivatable treponemes before and after absorption with various materials related to Reiter treponemes

\begin{tabular}{|c|c|c|c|c|c|c|}
\hline \multirow[b]{2}{*}{$\begin{array}{l}\text { Antisera } \\
\text { against }\end{array}$} & \multirow[b]{2}{*}{$\begin{array}{l}\text { Serum } \\
\text { number }\end{array}$} & \multirow{2}{*}{$\begin{array}{l}\text { Titre } \\
\text { before } \\
\text { absorption }\end{array}$} & \multicolumn{4}{|c|}{ Titre after absorption with: } \\
\hline & & & Sorbent & $\begin{array}{l}\text { Intact } \\
\text { Reiter }\end{array}$ & $\begin{array}{l}\text { Sonicated } \\
\text { Reiter }\end{array}$ & $\begin{array}{l}\text { Reiter } \\
\text { protein }\end{array}$ \\
\hline Whole Reiter & $\begin{array}{l}4,186 \\
4,189\end{array}$ & $\begin{array}{l}80^{\star} \\
80\end{array}$ & $\begin{array}{r}10 \\
5\end{array}$ & $\begin{array}{l}0 \\
0\end{array}$ & $\begin{array}{l}0 \\
0\end{array}$ & $\begin{array}{l}0 \\
0\end{array}$ \\
\hline Sonicate of Reiter & $\begin{array}{l}4,207 \\
4,208\end{array}$ & $\begin{array}{l}320 \\
320\end{array}$ & $\begin{array}{l}20 \\
20\end{array}$ & $\begin{array}{l}0 \\
0\end{array}$ & $\begin{array}{l}0 \\
0\end{array}$ & $\begin{array}{l}0 \\
0\end{array}$ \\
\hline English Reiter & $\begin{array}{l}374 \\
375\end{array}$ & $\begin{array}{r}640 \\
80\end{array}$ & $\begin{array}{l}20 \\
40\end{array}$ & $\begin{array}{l}0 \\
0\end{array}$ & $\begin{array}{l}0 \\
0\end{array}$ & $\begin{array}{l}0 \\
0\end{array}$ \\
\hline Kazan & $\begin{array}{l}287 \\
288\end{array}$ & $\begin{array}{r}160 \\
80\end{array}$ & $\begin{array}{l}10 \\
10\end{array}$ & $\begin{array}{l}0 \\
0\end{array}$ & $\begin{array}{l}0 \\
0\end{array}$ & $\begin{array}{l}5 \\
0\end{array}$ \\
\hline FM & 168 & 80 & 10 & 0 & 0 & 0 \\
\hline$\overline{\text { MRB }}$ & $\begin{array}{l}166 \\
167\end{array}$ & $\begin{array}{r}160 \\
80\end{array}$ & $\begin{array}{l}20 \\
10\end{array}$ & $\begin{array}{l}\mathbf{0} \\
\mathbf{0}\end{array}$ & $\begin{array}{l}0 \\
0\end{array}$ & $\begin{array}{l}0 \\
0\end{array}$ \\
\hline $\mathrm{N}-39$ & $\begin{array}{l}163 \\
165\end{array}$ & $\begin{array}{r}40 \\
160\end{array}$ & $\begin{array}{l}10 \\
20\end{array}$ & $\begin{array}{l}0 \\
0\end{array}$ & $\begin{array}{l}0 \\
0\end{array}$ & $\begin{array}{l}0 \\
0\end{array}$ \\
\hline Nichols & 326 & 10 & 0 & 0 & 0 & 0 \\
\hline$T$. vincentii & $\begin{array}{l}327 \\
328\end{array}$ & $\begin{array}{l}40 \\
80\end{array}$ & $\begin{array}{r}0 \\
10\end{array}$ & $\begin{array}{l}0 \\
0\end{array}$ & $\begin{array}{l}0 \\
0\end{array}$ & $\begin{array}{l}0 \\
0\end{array}$ \\
\hline T. zuelzerae & 265 & 320 & 20 & 0 & 0 & 5 \\
\hline T. pallidum & 481 & 2,560 & 160 & 320 & 160 & 160 \\
\hline
\end{tabular}


TABLE II Anti-Reiter treponeme reactivity of rabbit antisera to cultivatable treponemes before and after absorption with various Reiter-related materials

\begin{tabular}{|c|c|c|c|c|c|c|}
\hline $\begin{array}{l}\text { Antisera } \\
\text { against }\end{array}$ & $\begin{array}{l}\text { Serum } \\
\text { number }\end{array}$ & $\begin{array}{l}\text { Titre } \\
\text { before } \\
\text { absorption }\end{array}$ & \multicolumn{4}{|c|}{ Titre after absorption with: } \\
\hline Sonicate of Reiter & $\begin{array}{l}4,207 \\
4,208\end{array}$ & $\begin{array}{l}80 \\
80\end{array}$ & $\begin{array}{l}10 \\
20\end{array}$ & $\begin{array}{l}0 \\
0\end{array}$ & $\begin{array}{l}0 \\
0\end{array}$ & $\begin{array}{l}0 \\
0\end{array}$ \\
\hline Kazan & $\begin{array}{l}287 \\
288\end{array}$ & $\begin{array}{r}160 \\
40\end{array}$ & $\begin{array}{l}40 \\
20\end{array}$ & $\begin{array}{l}0 \\
0\end{array}$ & $\begin{array}{l}0 \\
0\end{array}$ & $\begin{array}{l}0 \\
0\end{array}$ \\
\hline FM & 168 & 40 & 20 & 0 & 0 & 0 \\
\hline MRB & $\begin{array}{l}166 \\
167\end{array}$ & $\begin{array}{r}160 \\
40\end{array}$ & $\begin{array}{l}20 \\
10\end{array}$ & $\begin{array}{l}0 \\
0\end{array}$ & $\begin{array}{l}0 \\
0\end{array}$ & $\begin{array}{l}0 \\
0\end{array}$ \\
\hline Nichols & 326 & 10 & 0 & 0 & 0 & 0 \\
\hline$T$. vincentii & $\begin{array}{l}327 \\
328\end{array}$ & $\begin{array}{l}10 \\
40\end{array}$ & $\begin{array}{l}0 \\
5\end{array}$ & $\begin{array}{l}0 \\
0\end{array}$ & $\begin{array}{l}0 \\
0\end{array}$ & $\begin{array}{l}0 \\
0\end{array}$ \\
\hline T. zuelzerae & 265 & 5 & 5 & 0 & 0 & 0 \\
\hline T. pallidum & 481 & 640 & 40 & 0 & 20 & 20 \\
\hline
\end{tabular}

*Results are expressed as reciprocals of last dilutions having at least $1+$ degree of fluorescence. Quantitation was performed as described under "Material and Methods"

with Reiter protein antigen eliminated the reactivity of all sera with Reiter antigen and of all but two sera with $\mathrm{Tp}$ antigen. In contrast, absorption with sorbent did not abolish either the anti-Tp or anti-Reiter reactivity from the hyperimmune sera, except in the instances of the antiserum to Nichols cultivatable strain and one of the antisera to $T$. vincentii. The fifteen sera that remained reactive after sorbent treatment had titres of $1: 5$ to $1: 40$, and all showed moderate to strong fluorescence $(2+, 3+, 4+)$ at the $1: 5$ dilution.

The antibody titre of the anti-Tp serum versus $T p$ antigen (Table I) was reduced approximately the same amount by absorption with any of the absorbents, but the homologous reactivity was not eliminated. It is interesting to note that only absorption with intact Reiter organisms completely removed cross-reactivity of the anti-Tp serum against Reiter antigen.

The effect that autoclaving had on the absorptive ability of the Reiter sonicate is depicted in Table III. The sonicate, which before heat treatment, had effectively removed anti-Tp cross reactivity from nine representative hyperimmune sera against cultivatable treponemes, was only able to eliminate the reactivity in three of the sera after being heated in the same manner as used in the preparation of sorbent.

TABLE III Effect of heat on absorptive ability of Reiter sonicate

\begin{tabular}{|c|c|c|c|}
\hline \multirow{2}{*}{$\begin{array}{l}\text { Antisera } \\
\text { against: }\end{array}$} & \multirow{2}{*}{$\begin{array}{l}\text { Serum } \\
\text { number }\end{array}$} & \multicolumn{2}{|c|}{$\begin{array}{l}\text { Reactivity with } \mathrm{T} \text {. pallidum } \\
\text { after absorption with: }\end{array}$} \\
\hline & & $\begin{array}{l}\text { Unheated } \\
\text { Reiter } \\
\text { sonicate }\end{array}$ & $\begin{array}{l}\text { Heated }\left(120^{\circ} \mathrm{C} .\right) \\
\text { Reiter sonicate }\end{array}$ \\
\hline $\begin{array}{l}\text { Whole Reiter } \\
\text { Sonicate of Reiter } \\
\text { English Reiter } \\
\text { Kazan } \\
\text { FM } \\
\text { MRB } \\
\text { N-39 } \\
T \text {. vincentii } \\
T \text {. zuelzerae }\end{array}$ & $\begin{array}{r}4,186 \\
4,207 \\
375 \\
288 \\
168 \\
166 \\
165 \\
328 \\
265\end{array}$ & $\begin{array}{l}- \\
- \\
z \\
- \\
-\end{array}$ & $\begin{array}{l} \pm \\
2+ \\
1-2+ \\
1+ \\
\pm \\
\pm \\
1+ \\
1+ \\
1-2\end{array}$ \\
\hline$T$. pallidum & 481 & $4 \div$ & $4 \div$ \\
\hline
\end{tabular}

\section{Discussion}

The results presented illustrate that different products of Reiter treponemes vary in their ability to remove reactivity from hyperimmune rabbit sera produced against a number of nonpathogenic cultivatable 
treponemes. In the light of previous work (Király, Jobbágy, and Kováts, 1967; Deacon and Hunter, 1962; Meyer and Hunter, 1967) demonstrating antigens common to many cultivatable and pathogenic spirochaetes, it was not unexpected that absorption with intact Reiter, Reiter sonicate, or Reiter protein antigen removed the anti-Tp crossreactivity demonstrated by heterologous antisera (Table I).

The reasons for the failure of sorbent to eliminate the anti-Tp reactivity in the hyperimmune rabbit sera are not clear. A likely explanation is one of quantity. Since the sorbent concentration for routine testing of human sera is adjusted so that it removes reactivity from a number of human nonsyphilitic sera having so-called natural anti-treponemal reactivity, it is conceivable that the sorbent is not concentrated enough to absorb reactivity from hyperimmune rabbit sera against nonpathogenic treponemes. Moreover, the antibodies stimulated in the hyperimmunized rabbits may differ from the natural antibodies found in humans by such factors as immunoglobulin class, affinity, and specificity. Unknown species differences may also be operative.

It also must be kept in mind that the action mechanism of the sorbent is not well understood. Several workers have reported that uninoculated Reiter media, several components of the media, and a variety of substances seemingly unrelated to treponemes are effective in removing reactivity of nonsyphilitic human sera (Cannefax, Hanson, and Skaggs, 1968; Rathlev, 1968; Wilkinson and Ferguson, 1968). Although these were preliminary studies representing relatively small numbers of sera, these accounts raise the possibility that perhaps the sorbent activity is not accomplished simply through a binding of natural antibodies by sorbent antigen.

Another conceivable explanation for the lack of complete absorbing activity of the sorbent regarding rabbit immune sera is perhaps the inactivation of some antigens by the heat treatment used in its preparation. Bredt (1965) and Bredt and TupathBarniske (1967) have suggested the existence of heatlabile and heat-stable antigens common to Reiter and $T p$. Our results have shown a reduction of the absorbing efficiency of the Reiter sonicate following heating at $121^{\circ} \mathrm{C}$.

In the United States, the fluorescent treponemal antibody-absorption (FTA-ABS) test (USPHS, 1969) is the treponemal test most widely used for the detection of antibodies to Treponema pallidum. The absorption aspect of the procedure, which is used to remove natural anti-treponemal reactivity present in a significant proportion of presumed nonsyphilitic individuals (Hunter and others, 1968), is currently performed by adding to the serum being tested a measured amount of sorbent. From a practical standpoint, the sorbent and the criteria used for selection of proper sorbent concentrations are quite effective, for numerous evaluations attest to the general sensitivity and specificity of the current FTA-ABS procedure (Hunter and others, 1968). Because the FTA-ABS test is a biological assay there is always the possibility that, in some instances, reactivity may be induced by stimuli other than infection with $T_{p}$ or related pathogenic treponemes.

Keeping in mind the limitations and hazards of extending the results of animal experiments to situations concerning human sera, and keeping in mind that the FTA-ABS test was developed and calibrated for human and not rabbit sera, it is possible that the results reported here may have bearing on the infrequent but puzzling FTA-ABS reactivity found in a small percentage of presumed non-syphilitic humans (Hunter and others, 1968; Mackey, Price, Knox, and Scotti, 1969). Although such reactivity may be due to cryptic infection with $T p$ or other pathogenic treponemes, or other unknown causes, it is conceivable that some of the presumed nonsyphilitic reactors may have an unusually high titre of antibodies stimulated by saprophytic treponemes present in the mouth or other parts of the body. In this postulate the high titre of antibodies to the nonpathogenic treponemes might outweigh the action of the usual concentration of sorbent and could be detected as reactivity in the FTA-ABS test.

\section{Summary}

Rabbit hyperimmune antisera experimentally produced against nonpathogenic treponemes were tested in an indirect fluorescent antibody assay modelled on the fluorescent treponemal antibodyabsorption (FTA-ABS) test. The FTA-ABS test sorbent at the concentration currently used for testing human sera eliminated the reactivity to $T p$ antigen from only two of seventeen of the hyperimmune rabbit sera. The reactivity in all sera could be eliminated by absorption with intact or sonically disrupted Reiter and in fifteen of the seventeen sera by absorption with Reiter protein antigen. The absorbing effectiveness of Reiter treponemes was found to be, in part, heat labile.

\section{References}

BREDT, W. (1965) Z. Hyg. Infekt.-Kr., 151, 366

and Tupath-Barniske, R. (1967) Arch. klin. exp. Derm., 229, 117 
Cannefax, G. R., Hanson, A. W., and Skaggs, R. (1968) Publ. Hlth Rep. (Wash.), 83, 411

D'alessandro, G., and Zaffiro, P. (1962) Riv. Ist. sieroter. ital., 37, 532

Deacon, W. E., and Hunter, E. F. (1962) Proc. Soc. exp. Biol. (N.Y.), 110, 352

Hunter, E. F., Deacon, W. E., and MeYer, P. E. (1964) Publ. Hlth Rep. (Wash.), 79, 410

—, Norins, L. C., Falcone, V. H., and Stout, G. W. (1968) Bull. Wld Hlth Org., 39, 873

KIRÁLY, K., JOBBÁGY, A., and KovÁts, L. (1967) F. invest. Derm., 48, 98

Mackey, D. M., Price, E. V., Knox, J. M., and Scotti, A. (1969) f. Amer. med. Ass., 207, 1683

MeYer, P. E., and Hunter, E. F. (1967) f. Bact., 93, 784

Rathlev, T. (1968) Brit. f. vener. Dis., 44, 295

Stout, G. W., Kellog, D. S., Falcone, V. H., McGrew, B. E., and LewIS, J. S. (1967) Hlth Lab. Sci., 4, 5

USPHS (1969) "Manual of Tests for Syphilis, 1969", US Communicable Disease Centre, PHS Publication No. 411. U.S. Government Printing Office, Washington, D.C.
Wilkinson, A. E., and Ferguson, B. G. (1968) WHO/ VDT/RES/68.148

Réactivité de l'Épreuve FTA-ABS chez des lapins hyper-immunisés par inoculation de tréponèmes non pathogènes

SOMMAIRE

Des sérums anti-lapin hyper-immunisé expérimentalement avec des tréponèmes non pathogènes furent éprouvés dans un essai de recherche de l'anticorps fluorescent indirect, dérivé du test de recherche de l'anticorps fluorescent tréponèmique absorbé (FTA-ABS). L'absorbat pour le FTA-ABS, à la concentration habituelle pour l'épreuve sur sérums humains, a fait disparaitre la réactivité à l'antigène TP pour 2 seulement des 17 sérums anti-lapin hyper-immunisé. Pour tous les sérums, la réactivité put être éliminée par absorption avec $T$. Reiteri, intacts ou ultrasonnés, et pour 15 des 17 sérums, par absorption avec l'antigène protidique de Reiter. L'action absorbante des tréponèmes de Reiter a été trouvée partiellement thermo-labile. 